\title{
Using the PVI (People Value Index) Tool to Enhance Project Success
}

\section{(Identifying an Individuals' Personal Knowledge Base to Align Employee Attributes for Project Success)}

\author{
Kathleen Y. Terry \\ The TEEG Group, L.L.C., Alpharetta, Georgia, USA \\ and St Leo University, Florida, USA
}

\section{kphd@bellsouth.net Kathleen.terry@saintleo.edu}

\begin{abstract}
Material published as part of this publication, either on-line or in print, is copyrighted by the Informing Science Institute. Permission to make digital or paper copy of part or all of these works for personal or classroom use is granted without fee provided that the copies are not made or distributed for profit or commercial advantage AND that copies 1) bear this notice in full and 2) give the full citation on the first page. It is permissible to abstract these works so long as credit is given. To copy in all other cases or to republish or to post on a server or to redistribute to lists requires specific permission and payment of a fee. Contact Publisher@InformingScience.org to request redistribution permission.
\end{abstract}

Nearly $68 \%$ of all projects are "off the rails or fail" according to CIO.COM. Project failure stems from two fundamental components, decision making capacity and process failure. Every project, no matter how big and global, or small and departmental, will have one thing in common. They will have a project manager to lead the process and team members to assist in the completion. In addition, highly specialized software is often used to track the moving pieces, timelines and expenditures. To aid in the process, Gant Charts, Excel Spreadsheets, Power Point, and off the shelf or proprietary software are used. With all these components, technology and knowledge, projects still have a $68 \%$ failure rate. Focusing on people assets may be the key to a successful project. In today's fast-paced business world, organizations large and small need to take advantage of every asset. Physical assets are relatively easy to assess and apply, but physical assets are a small part of the value of an organization. 80 to $90 \%$ of an organization's value is in its people assets.

A tangible asset can be recognized and listed on the balance sheet. Alternatively, intangible assets are non-physical items (e.g. people, patents, knowledge, and competencies). The problem is managers are not able to easily recognize and articulate the value of intangible assets, including the value of knowledge management initiatives in their organizations (Forsyth, 2007).

There are two distinct and complementary tasks that are required to take full advantage of what we call "individual assets" in an organization: the capabilities, competencies, and tacit knowledge possessed by individual employees. They are: determine the assets (people) and apply those assets (people) to the needs of the organization. This article introduces the PVI System (People Value Index) which incorporates the P3 (People Asset, Process Management, Power Execution) components. The article brings attention to understanding information from peoples' knowledge, understanding the concepts behind the value theory and knowledge management concepts, and introducing the PVI Tool. These combined together; enhance project management success by utilizing tacit and explicit knowledge from project managers.

Keywords: Project Management, P3 (People Asset, Process Management, Power Execution), PVI System (People Value Index System), Knowledge Man- 
agement, Tacit Knowledge, Explicit Knowledge, Value Theory

\section{Introduction}

In today's fast moving markets, money is attracted to speed. The principle of "speed equals money" is the primary goal for projects in a business environment. However, business owners and executives often lack the ability to easily track failing projects and thus their detriment to the bottom line. Projects in organizations, large and small, are chronically over budget and over time. Ironically, projects are measured for success using instruments that all track time and money. For a project performance solution to be worth the investment, it better fix the problem. $P^{3}$ (People Asset, Process Management and Power Execution) are the combined integrated parts. Each piece specifically helps mangers build from the ground up or from existing groups, high performance project teams; by assessing, building and executing at levels far beyond current capabilities.

Most managers believe that subjective measures and project planning are sufficient for project success and rely on common sense to fill in the gaps. Unfortunately, organizations do not have common sense. They can't - common sense requires a thinking organism. The PVI System ${ }^{\mathrm{TM}}$ is common sense for organizations - it streamlines and improves the tasks that would rely on common sense: getting the right capabilities in the right positions, getting the right tacit and explicit knowledge in the right place for effective decision-making and making sure that project execution proceeds efficiently.

\section{P3 - People Assets, Process Management, Power Execution}

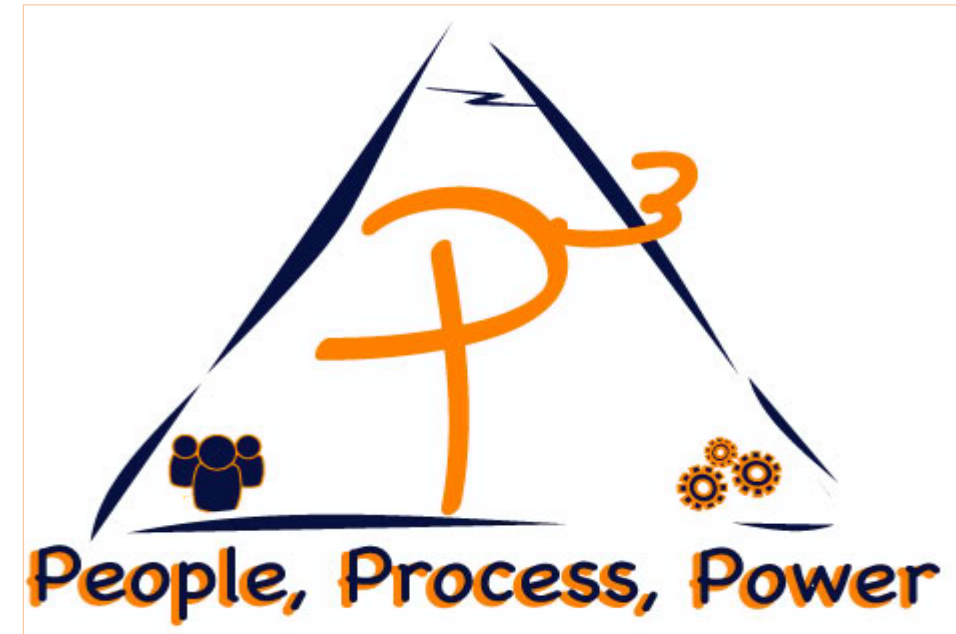

Figure 1: Datalynx website, 2012

(http://www.datalynx.ch/site/index.php?option=com content\&view $=$ article\&id $=5 \& I t e m i d=17)$

\section{P1: People Asset}

In today's fast-paced business world, organizations both large and small need to take advantage of every asset they possess. Physical assets are relatively easy to assess and apply, but physical 
assets are a small part of the value of an organization. 80 to $90 \%$ of an organization's value is in its people. The wrong personnel on a project can be detrimental to the team or the entire project. On the other hand, knowing that you have the right people for the job with project management competency can infinitely enhance even the most difficult projects. So how do you really know if you have the right people for project managers and team make up? These are very difficult questions to answer. In the past, managers could only use subjective testing to determine personality traits and skill sets. Natural science explains human behavior. Science mathematically measures intangibles values as it measures the structure of human thought, which form the foundation for, and lead to behavior. As opposed to other assessments, that solely measure behavior. You can predict how a person thinks and makes decisions in your environment. Also, DO they have the capacity to access their talent for you? Are their biases so pronounced that team chemistry is diminished? Will they do what they tell you they will do? These are questions that area included in the context of the assessment of skills necessary for project management.

\section{P2: Process Management}

Process management has many different approaches. Using a Knowledge Management (KM) system approach based on the Baldridge Award framework helps structure processes throughout the entire organization. The framework is designed to create more of a system where human competence and relationships served as a foundation to greater performance. There is an emphasis on leadership, strategic planning, customer focus, human resources, process management, and, business results, as was the case in the original Baldridge framework, however, the questions to be answered in implementation were all created to build a KM system.

Evans and Lindsay (2002) noted the similarities between the Malcolm Baldridge Categories and the balanced scorecard. These two methods were said to be close enough in structure that the recommended Malcolm Baldridge criteria could be utilized in the scorecard framework and be acceptable for the performance excellence award (Svieby, 2001). The balanced scorecard is used on a regular basis in project management. This approach directly supports the P3 concepts by providing information for the PVI System assessment.

\section{P3: Power Execution}

Execution Management is a key principle to any projects long term success. Execution Management has become a common buzz word used in business. In reality, project execution is difficult, illusive and is often misunderstood. Every predetermined task that gets done inside of a project is a function of execution. What about the daily "business storm", all the must do, urgent tasks pushing on you without which, the business or project doesn't function...is that execution? Project Execution seems so common sense, but for most business operations it's not common practice! Power Execution provides a solution to focus on 2-3 strategic goals; it acts as a highly visible scoreboard that can keep a global team laser focused on individual commitments every step of the way. Management teams are able to view reports and project status in real time looking through the front window rather than the rearview mirror. If you aren't keeping a highly visible score board, goals never become reality. This component makes the disciplined principles of project execution easy and highly visible for project team and executive team members. The P3 concepts provide information that are incorporated into The PVI System ${ }^{\mathrm{TM}}$ assessment component that is the PVI itself: the People Value Index

The assessment yields reports that indicate the critical reasons for how he or she thinks and weighs their decision-making capacity, and how that will be applied (talent) to your project. The People Value Index mathematically measures intangible values: it measures the unconscious and subconscious values that form the foundation for an individual's behavior and capabilities. Other assessments measure behavior alone. 
The People Value Index results know how a person thinks and makes decisions. More importantly, do they have capacity to tap into and efficiently access their knowledge, talents, and experience for you? Are their biases so pronounced that team chemistry is diminished? Will they do what they tell you they will do? Answers to questions such as these are vital to project execution.

\section{PVI Execution Tool}

Accountability and visibility are the key principles necessary for any project's long term success. Execution Management has become a common buzzword used in business, primarily because all the planning in the world is insufficient if you don't execute a plan. Execution is difficult, elusive and is often misunderstood. Every planned task that gets done inside of a project is a function of execution? What about the daily "routine", all the must-do, urgent tasks pushing on you, without which the business doesn't operate? Is that execution? Well, yes, but its competing execution. For individuals, or small projects, we rely on our common sense to balance competing priorities. As the size and importance of competing projects increases, individuals tend to lose sight of the important goals required for efficient execution. Commitment to team goals may be common sense, but for most it's not common practice - not because people are lazy or aren't team players, but because of the short-range thinking required by the daily "routine."

The PVI Execution Tool provides a cloud software solution for laser focus on 2-3 strategic goals; it acts as a highly visible scoreboard that can keep a global team focused on individual commitments every step of the way. It gives everyone visibility to the leading and lagging indicators of your strategic goals. Management teams will be able to view reports and strategic project status in real time, and look at leading indicators as they develop, rather than wait for lagging results. It's like looking through the front window and seeing clearly the road ahead, rather than trying to drive using the rearview mirror. If you aren't keeping a highly visible score board, goals never become reality. This is a tool to change and track behavior and to move people to a much higher level of personal and team performance.

\section{The Science behind the Tool}

The science behind the tool is based on the value theory. People think and make decisions through three core dimensions: Intrinsic, Extrinsic, and Systemic. It is possible to measure how people think and make decisions (measuring the intangible thoughts). Dr. Robert S. Hartman developed the axioms of formal axiology. The result of collecting these axioms becomes the People Value Index. The assessment indicates the critical reasons for how the subject thinks and weighs their decision-making capacity, and how that will be applied to projects. The PVI tool mathematically measures intangible values: it measures the unconscious and subconscious values that form the foundation for an individual's behavior and capabilities. The tool assessments measure behavior alone.

\section{What does it Measure?}

The PVI System Tool enables the manager to identify internal valuing systems and their influence on perceptions, decisions, and actions. The tool gathers unbiased data to identify performance strengths and development needs for Individuals. It gives you the ability to: See and filter what is happening around you, and inside yourself; Build concepts and ideas by focusing on what is important to you; and translate your ideas and expectations into decisions, which ultimately become your results. 


\section{Background Information on Knowledge and Information - How is it Valued in an Organization?}

Purely explicit information or data management might best be addressed through an information technology (IT)/management group, or perhaps the human resources group depending on the content or context; whereas, a knowledge engineer or someone else who truly understands KM might best address the retrieval and storage of tacit knowledge. There is an economic value to this connection. Asking questions such as, how could our knowledge foster sound decision-making or innovation? How do these knowledge factors impact the income statement or balance sheet? How then are both individual and group knowledge cognized? Questions leading to these answers might include how do individuals or groups get creative, learn experientially, typically solve problems and collaborate? What are the current norms and patterns that need to be enhanced or altered, or just left alone? There might be a technology factor to answer most of these questions. Here one could ask what role technology will play in this architecture. There is danger that the technology aspect of the architecture could dominate the program and that potential problem would need to be addressed. If technology is to be a dominant component of the program, then let it be by design and for a purpose. Just as we need a mission and business model to guide strategic thought about our corporations, we could use business epistemology to guide strategic decisions about how to manage knowledge in our corporations. (Clare and Detore, 2000).

Clare and Detore (2000) theorized that in order for knowledge to be categorized as an asset, it would need to have three distinguishing factors, which were content, structure and reasoning. The content is data or information in its purest form before the real value has been added by human interaction and utilization. Once there is the presence of some content, the data or information would need to have some structure such as a hierarchy or some scheme or categorization, which would create logic and understanding for others engaged in the usage of this data/information. The reasoning component is the active cognitive process that the human factor would necessarily add to the data/information in order to create required value. Sound problem solving or decisionmaking by the user creates this value. Individuals or groups, to varying degrees of success, can accomplish this reasoning element. This success would largely depend on the intentional design of a structured architecture along with the understanding of the users in how to create value. In order to further define their theory of intangible asset valuation, Clare and Detore (2000) reviewed some of the literature on systems theory and attempted to create a link between constructs such as core competencies, value constellations, and mental models in order to advance Knowledge and Organizational Learning Management (K \& OLM) in organizational systems.

The fundamental way in which organizational systems have been required to organize and perform as of late have been changing at a phenomenal rate unlike any other in history. Mergers and acquisitions, downsizing, critical skill shortages in our culture, globalization, and a host of other factors are impacting the way in which systems are required to evolve. If, in fact, the requirements to be a successful competitor in the global economy include creating and sustaining a culture of innovation, quality, and continuous improvement, then it is also logical to assume that the argument could be made for investment in K\&OLM. Knowledge and its relationship to changes in organizational systems could be summed up as follows: Knowledge is a key factor of production in every industry and is the scarcest resource around which the business firm competes. Innovations in communication and coordination technologies are causing a shift in the relative transaction cost advantage of firms causing an explosion of innovation in the shape and structure of the modern firm as it reconfigures to increase the value created by knowledge and to learn faster than competitors. (Clare and Detore, 2000). 


\section{Conclusion}

With the influence of the knowledge age and invisible assets as described by Sveiby (1997), it becomes apparent that the business world is shifting in favor of invisible assets and it is time for the accounting profession to take notice and adjust their ways to reflect modern issues and trends. Project Management uses the accounting system to identify profits and losses upon project completion.

This article presents the PVI System Tool, which enables the manager to identify internal valuing systems and their influence on perceptions, decisions, and actions. One key recommendation is that managers should consider disciplined methods to assess intangible assets because these variables contribute to company earnings. From a positive social change perspective, an increased awareness of the importance of intangible assets may help managers make appropriate investment decisions regarding knowledge management and other organizational change initiatives that could lead to further profitable growth and success of organizations (Forsyth, 2007).

Knowing that the knowledge management field continues to need empirical research on intangibles, this study begins to contribute to increasing the awareness of this aspect of intangible assets and introducing a tool that supports this concept. Further research and writing on this topic is necessary to uncover the potential of the PVI Tool and its uses and how it contributes to the Value Theory and Knowledge Management.

Overall, an awareness of such tools as the PVI Tool can be utilized in organizations to enhance project success. Furthering this study is the overall objective through identifying constructs from the PVI Tool that map directly to the Value Theory and Knowledge Management.

\section{References}

Block, W. (1998). The necessity of free trade. Journal of Markets and Morality, 1, 192-200.

Borghoff, U., \& Pareschi, R. (1998). Information technology for knowledge management. New York: Springer-Verlag.

Chazan, G. (2008, October 14). Iraq invites new foreign oil bids, seeking funds to double production, The Wall Street Journal, p. A12.

Chon, G. (2008, August 13). Iraq, foreign companies stalled in oil negotiations. The Wall Street Journal, p. A6.

Clare, M., \& Detore, A (2000). Knowledge assets: Professional's guide to valuation and financial management. New York: Harcourt Professional Publishing.

Davenport, T. H., \& Prusak, L. (1998). Working knowledge: How organizations manage what they know. Boston: Harvard Business School Press.

Drucker, P. (1987). The coming of the new organization. Boston: Harvard Business School Press.

Evans, J., \& Lindsay, W. (2002). The management and control of quality. Cincinnati, OH: South-Western.

Forsyth, B. (2007). A validation study on the intangibles audit. Walden University). ProQuest Dissertations and Theses. Retrieved from http://ezproxy.saintleo.edu/login?url=http://search.proquest.com/docview/304770562?accountid=4870

Hammer, M., Leonard, D., \& Davenport, T. (2004). Why don't we know more about knowledge? Sloan Management Review, 45(4), 14-18.

Howell, M., \& Prevenier, W. (2001). From reliable sources: An introduction to historical methods. Ithaca, NY: Cornell University Press.

Isaac, R. G., Herremans, I. M., \& Kline, T. J. B. (2009). Intellectual capital management: Pathways to wealth creation. Journal of Intellectual Capital, 10(1), 81-92. 
Khalaf, R., \& Negus, S. (2008, March 20). Forbidden fields: Oil groups circle the prize of Iraq's vast reserves. The Financial Times, p. 43.

Kleiner, A., \& Roth, G. (1997). How to make experience your company's best teacher. Boston: Harvard Business School Press.

Knapp, E. (1998). Knowledge management. Business and Economic Review, 44(4), 3-6.

Leonard, D., \& Straus, S. (1997). Putting your company's whole brain to work. Harvard Business Review, $75(4), 110-120$.

Levy, F. (2009). A simulated approach to valuing knowledge capital. The George Washington University). ProQuest Dissertations and Theses. Retrieved from http://ezproxy.saintleo.edu/login?url=http://search.proquest.com/docview/288395892?accountid=4870

Malhotra, Y. (1998). Tools at work: Deciphering the knowledge management hype. Journal for Quality and Participation, 21(4), 58-60.

Nonaka, I. (1994). Dynamic theory of organizational knowledge creation. Organization Science, 5, 14-37.

Nonaka, I. (1998). The knowing-creating company. Boston: Harvard Business School Press.

Plowman, D., \& Hancock, P. (2008). The evolving research on intellectual capital. Journal of Intellectual Capital, 9(4), 585-608.

Polanyi, M. (1966). Tacit dimension. London: Routledge \& Kegan Paul.

Prahalad, C. (1997). The work of new age managers in the emerging competitive landscape. In F. Hesselbein, M. Goldsmith, \& R. Beckhard (Eds.), The organization of the future (pp. 159-168). San Francisco: Jossey-Bass.

Probst, G., Raub, S., \& Romhardt, K. (2000). Managing knowledge: Building blocks for success. West Sussex, UK: John Wiley.

Root, F. (1994). Entry strategies for international markets. San Francisco: Jossey-Bass.

Senge, P. (1990). The fifth discipline: The art and practice of the learning organization. New York: Doubleday.

Sveiby, K. (1997). The new organizational wealth: Managing \& measuring knowledge based assets. San Francisco: Berrett-Koehler Publishers, Inc.

Thurm, S. (2006, January 3). Companies struggle to pass on knowledge that workers acquire. The Wall Street Journal. p. B1.X.

Tuten, P. M. (2009). A model for the evaluation of IS/IT investments. (Nova Southeastern University). ProQuest Dissertations and Theses. Retrieved from http://ezproxy.saintleo.edu/login?url=http://search.proquest.com/docview/305150683?accountid=4870

Widén-Wulff, G., \& Suomi, R. (2007). Utilization of information resources for business success: The knowledge sharing model. Information Resource Management Journal, 20(1), 46-67.

Williams, L. (2004). A performance evaluation framework for a public university knowledge management system. The Journal of Computer Information Systems, 44(3), 9-16. Retrieved from http://ezproxy.saintleo.edu/login?url=http://search.proquest.com/docview/232575966?accountid=4870

Zack, M. H. (1999). Managing codified knowledge. Sloan Management Review, 40(4), 45-58. 


\section{Biography}

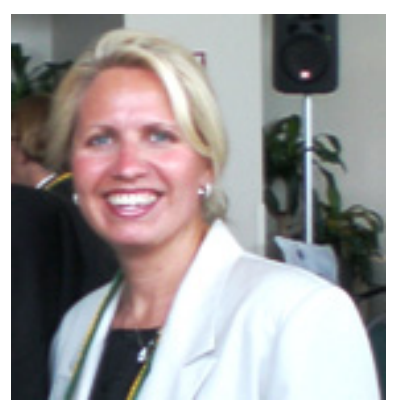

Kathleen Terry is a partner of TEEG Ventures LLC, a consulting business firm specializing in "Process Improvement within Organizations and Improving the Quality of Information and Cost/Expense Control." With over 18 years of management experience across a variety of industries: Medical, Financial, IT Software and Telecommunications, in conjunction with corporate experience, Kathleen has worked at various universities and colleges as an adjunct professor teaching Business Management and Information Management courses. Her areas of expertise over the years have been:

- Management of information systems;

- Quality processes surrounding Operations and Information System Technology;

- Strategic Organizational Restructuring;

- Change Management related to Mergers and Acquisitions and Organizational Restructuring;

- IT Strategic Management.

She has participated in national and international conferences published articles from the conference proceedings. She has also published articles for corporations in the areas of Strategic Management, Organizational Restructuring, Change Management and Quality Process Improvement.

Kathleen started her career in the medical profession as a registered nurse. She worked in medical facilities for approximately 15 years, leading other medical personnel in improving their daily work. She is a

- Licensed Registered Nurse;

- Undergraduate Degree in Business Management \& Information Technology Management;

- Masters in Business Management;

- Doctorate in Business Management / Entrepreneurship with Information Technology Management.

Other areas of experience acquired are in Etiquette Consulting training, mentoring business people in areas pursuing career changes and career advancement.

\section{Contributors: For further information on PVI System please contact:}

Norman Brodeur

US CEO Datalynx

5025 New Chapel Hill Way

Suite 101

Cumming, GA 30041

norman.brodeur@datalynx-us.com

Phillip Ray

VP Marketing and Production

Datalynx

5025 New Chapel Hill Way

Suite 101

Cumming, GA 30041

Phillip.ray@datalynx-us.com 